\title{
Detection of Immunoglobulin G Against Oral Streptococci in Peripheral and Umbilical Cord Blood
}

\section{Deteç̧ão de Imunoglobulin G Contra Estreptococos Orais em Sangue Periférico e do Cordão Umbilical}

\author{
Maria Lucia Talarico Sesso ; Sanivia Aparecida de Lima Pereirab; Vinicius Rangel Geraldo-Martins ${ }^{\mathrm{b}}$; Virginia Paes \\ Leme Ferriani ${ }^{a}$; Ruchele Dias Nogueira*b
}

\author{
${ }^{a}$ University of Sao Paulo, Department of Pediatrics, Medical School of Ribeirao Preto. SP, Brazil; \\ bUberaba University. MG, Brazil; \\ *E-mail: ruchele_nogueira@yahoo.com.br \\ Recebido em: 19/08/2020 \\ Aprovado em: 24/11/2020
}

\begin{abstract}
The maternal Immunoglobulin G (IgG) antibodies transferred during the intrauterine life represents the main newborn immune protection against several intestinal and respiratory infection. However, there is little information about the reactivity and function of IgG from cord blood against newborn oral colonization. The aims this study was to evaluate the presence of IgG against Streptococcus mitis, Streptococcus mutans and theirs mains virulence antigens (GbpB, Ag I/II and Gtf) in peripheral blood (PB) samples from mothers with $S$. mutans or not in the saliva (SA) and compare with umbilical cord blood (CB). PB and SA samples were obtained from healthy women in the Hospital admission and CB was collected after delivery. The specificity of IgG against the bacterial extracts was determined by Western blot. The genetic material detection of $S$. mutans in the salivas was realized by the quantitative polymerase chain reaction with specific primers. The results showed that the minority of blood samples showed IgG against $S$. mitis. On the other hand, the majority of samples exhibited IgG anti $S$. mutans. The number of reactive bands to $S$. mutans was significantly higher than against $S$. mitis in both blood samples ( $<<0.05)$. The IgG anti-GbpB detection was more frequent than IgG anti-Ag I/II or anti-Gtf $(\mathrm{p}<0.05)$. The IgG antibody response pattern to $S$. mutans was similar in PB and CB pairs. There was no difference in the IgG anti-S. mutans detection and its virulence Ags ( $\mathrm{p}>0.05)$ in the PB from mothers colonized or not by $S$. mutans. In opposite, in CB sample, it was more frequent to find samples with IgG anti-S. mutans and GbpB in the salivas from mothers with detectable $S$. mutans $(\mathrm{p}<0.05)$. In conclusion, the blood samples possessed IgG-anti $S$. mutans and theirs virulence antigens; mainly IgG anti-GbpB. The lack of IgG against $S$. mitis transferred by CB can be related to the early $S$. mitis colonization in the first months of age. The similarity of bands recognized by $\mathrm{IgG}$ against $S$. mutans antigens detected in $\mathrm{PB}$ and $\mathrm{CB}$ is suggestive that maternal antibodies can be transferred to the fetus.
\end{abstract}

Keywords: Streptococcus mutans. Saliva. Fetal Blood. Immunoglobulin G.

\section{Resumo}

Os anticorpos Imunoglobulina $G$ (IgG) transferidos durante a vida intrauterina representam a principal proteção imunológica do recém-nascido contra diversas infecções intestinais e respiratórias. No entanto, poucas informações existem sobre a reatividade e função de IgG do sangue do cordão contra a colonização oral de recém-nascidos. Os objetivos deste estudo foram avaliar a presença de IgG contra Streptococcus mitis, Streptococcus mutans e seus principais antígenos de virulência (GbpB, Ag I / II e Gtf) em amostras de sangue periférico (SP) de mães com S. mutans detectável ou não na saliva (SA) e comparar com sangue do cordão umbilical (SC). Amostras de SP e SA foram obtidas de mulheres saudáveis na admissão do hospital e CB foi coletado após o parto. A especificidade de IgG contra os extratos bacterianos foi determinada por Western blot. A detecção do material genético de S. mutans nas salivas foi realizada pela reação em cadeia da polimerase quantitativa com primers especificos. Os resultados mostraram que a minoria das amostras de sangue apresentou IgG contra S. mitis. Por outro lado, a maioria das amostras exibiu IgG anti $S$. mutans. O número de bandas reativas para $S$. mutans foi significativamente maior do que contra $S$. mitis em ambas as amostras de sangue ( $p<0,05)$. A detecção de IgG anti-GbpB foi mais frequente do que IgG anti-Ag I/II ou anti-Gtf (p<0,05). $O$ padrão de resposta de anticorpos IgG contra $S$. mutans foi semelhante nos pares SP e SC. Não houve diferença na detecção de IgG anti-S. mutans e sua virulência Ags $(p>0,05)$ no SP de mães colonizadas ou não por $S$. mutans. Por outro lado, nas amostras $S C$, foi mais frequente encontrar amostras com IgG anti-S.mutans e GbpB em salivas de mães com $S$. mutans detectáveis ( $p<0,05)$. Em conclusão, as amostras de sangue possuíam IgG-anti $S$. mutans e seus antígenos de virulência; principalmente IgG anti-GbpB. A falta de IgG contra S. mitis transferida no SC pode estar relacionado a colonização precoce de S. mitis nos primeiros meses de idade. A semelhança de bandas reconhecidas por IgG contra antígenos de S. mutans detectados em SP e SC é sugestiva de que anticorpos maternos podem ser transferidos para o feto.

Palavras-chave: Streptococcus mutans. Saliva. Sangue Fetal. Imunoglobulina G.

\section{Introduction}

Streptococci correspond to the majority of commensal bacteria that firstly colonize the oral cavity. Streptococcus mitis is the main bacteria that initially colonize the oral cavity $^{1}$. After tooth eruption, new colonization sites arise and the oral microbiota becomes progressively more complex. The presence of non-desquamating dental surfaces is sufficient for colonization by Streptococcus mutans ${ }^{2}$. However, these species may also be detected in predentate children ${ }^{3}$,in children highly exposed to saccharose consumption and to contact with the saliva of highly infected individuals ${ }^{3,4}$ A high colonization with $S$. mutans is a risk for oral health since $S$. mutans is considered to be the main primary etiological agent of dental caries. Caries is a great public health problem 
especially in Brazil, where the levels of early caries are high, with evidence that infants aged 5 to 11 months already show high $S$. mutans levels detectable in the saliva ${ }^{3}$. Mothers seem to be the main sources of $S$. mutans infection in children ${ }^{5}$. In the first 48 hours of life, the newborn gains a major part of his or her oral microflora from his or her mother ${ }^{6}$.

S. mutans ability to adhere and to accumulate on smooth surfaces forming dental biofilms, and to metabolize carbohydrates and survive in low $\mathrm{pH}$ environments represent key factors of its virulence mechanisms. This microorganism produces glycosyltransferases (Gtfs) that may utilize saccharose to produce glucans, which are glucose exopolymers that, when combined with glucan-binding proteins (Gbps), favor the cariogenic streptococci cohesion and agglutination on the dental surface ${ }^{7}$. The past studies support the use of these antigens in clinical trials of caries vaccines in older children and adults ${ }^{8}$

The mucosa immune system represents the first line of the adaptive immune response defense against oral infectious challenges. The secretions antibacterial activity is mediated in part by the immunoglobulin $\mathrm{A}(\operatorname{Ig} \mathrm{A})$ present in the saliva. Complex pattern of salivary $\operatorname{IgA}$ reactivity to $S$. mutans antigens ${ }^{9}$ was found in heavily exposed children aged 5-24 months, suggesting that responses to virulenceassociated antigens, especially against $\mathrm{GbpB}$, may influence the $S$. mutans ability to colonize the oral cavity. At birth, babies have low levels of salivary IgA antibodies against the virulence antibodies of $S$. mutans, such as Ag I/II, Gtf and $\mathrm{GpbB}$, especially in premature infants, demonstrating that the repertoire of saliva IgA may not be able to combat the initial oral microbial colonization ${ }^{10}$.

Besides IgA, human saliva have IgG transported to the oral cavity, via gingival crevicular fluid, mucosal transudate and ultrafiltration through the salivary gland acini ${ }^{11}$. There is a lack of data in the literature regarding the transport of immunoglobulins against $S$. mutans. Neonatal immunity depends on this intrauterine acquisition of $\operatorname{IgG}$ through active transplacental transport mediated by FcRn receptor ${ }^{12}$. Immunoglobulin $\mathrm{G}$, transferred during the intrauterine life, represents the main newborn immune protection and may contribute to the bacterial neutralization and exclusion processes and the establishment of intestinal microbiota ${ }^{13}$. The levels of transport in singleton pregnancies depend on gestational age, maternal IgG levels and IgG subclass ${ }^{14}$. Several studies have reported the specific IgG detection against various microbial types, which is of protective importance at the beginning of life and effective for formation and transfer to the fetus after antigen stimulation of pregnant woman. Specific IgG against Pseudomonas, Klebsiella, group B streptococci ${ }^{15}$ and Staphylococcus aureus ${ }^{16}$ was detected in umbilical cord.

The presence of $\operatorname{IgG}$ anti-S. mutans and its virulence antigens was found in human serum ${ }^{17,18}$ and saliva ${ }^{19}$. However, the IgG role in the $S$. mutans installation and accumulation processes is still controversial. IgG present in the gingival fluid can inhibit the $S$. mutans adhesion, neutralizing the enzymes, promoting the opsonization and consequent phagocytosis and/or activation of the complement system $^{20}$. Serum IgG antibodies to $S$. mutans cell-wall associated protein antigens were found more frequently in caries-free subjects ${ }^{17}$ and low caries experience has been associated with significantly higher serum $\mathrm{IgG}^{18,21}$. On the other hand, an association between IgG and caries levels ${ }^{22}$ was not detected and serum IgG and IgA levels were increased in patients with caries ${ }^{20}$.

Therefore, there is little information about the IgG immune response during the early stages of $S$. mutans bacterial challenge and the IgG role provided by umbilical cord blood against the installation of these bacteria. It is possible that some factors can affect the initial response of pioneer commensal species of the oral cavity, and influence the immune response patterns and the susceptibility to colonization. In the present study, the aims were to analyze the presence and specificity of IgG against oral streptococci and compared the reactivity of IgG to $S$. mutans and S.mitis extracts in umbilical cord blood (CB) and peripheral blood (PB) samples of mothers with detectable levels of $S$. mutans in the salivas samples (SA).

\section{Material and Methods}

\subsection{Study design}

Eighty pairs of pregnant women were enrolled in this study, under consent for their participation. The Ethical Committee of the Medicine School of Ribeirao Preto, Sao Paulo, Brazil, (protocol number 13290/2010), approved this study. To be included in the study population, health mothers were selected and submitted to cesarean delivery of full-term gestation without antibiotic therapy. Information about maternal and gestational background was obtained by interviewing the expectant mother on the first day of hospitalization. The exclusion criteria included placental and congenital malformation, chronic disease, and infectious disease during pregnancy. A subset of 33 mothers had the saliva collected to investigate the presence of genetic material of $S$. mutans.

\subsection{Samples collections}

The peripheral blood (PB) and salivas samples were collected from mothers in the first day of hospitalization. After delivery, the blood was drawn from the umbilical vein using a sterile needle and syringe. Whole saliva samples unstimulated were collected using sterile polypropylene transfer pipettes. Solution of $250 \mathrm{mM}$ EDTA, pH 5.2 (Sigma, St Louis, MO, USA) was added to each sample prior to transport on ice to the laboratory where they were stored at $-80^{\circ} \mathrm{C}$ until analysis.

\subsection{S. mutans detection in the salivas samples}

Firstly, the samples were incubated with lysozyme 
solution (Sigma, Tokyo, Japan) and then, genetic material was extracted with the PowerLyzer PowerSoil DNA Isolation Kit (MO-BIO, Carlsbad, CA) according to the manufacturer's instructions. The concentration of purified DNA product was measured with a NanoDrop 2000 spectrophotometer (Thermo Scientific). Sm479F/R primer pair (Sm479F: 5'-TCGCGAAAAAGATAAACAAACA-3' and Sm479R: 5'-GCCCCTTCACAGTTGGTTAG-3') that is highly specific and sensitive for identification of $S$. mutans in mixed DNA samples (23) purchased from Invitrogen (Tokyo, Japan). The StepOne ${ }^{\mathrm{TM}}$ Real-Time PCR System (Thermo Fisher Scientific) performed PCR. Each reaction tube contained reaction mixture, including 6.5 $\mu \mathrm{L}$ SYBR Green Master Mix (Roche, Ilhois, USA), $1 \mu \mathrm{L}$ of each primer, $4.5 \mu \mathrm{L}$ de ultrapure water e $2 \mu \mathrm{L}$ of DNA extracted from the samples. The cycling conditions were 45 cycles of $15 \mathrm{~s}$ at $94{ }^{\circ} \mathrm{C}$ for denaturation, $30 \mathrm{~s}$ at $56{ }^{\circ} \mathrm{C}$ for annealing, and $30 \mathrm{~s}$ at $72{ }^{\circ} \mathrm{C}$ for extension followed by a melting curve analysis of the PCR product. Two PCR reactions were performed for all the samples. To positive control DNA from Streptococcus mutans was used (UA159).

\subsection{IgG reactivity against streptoccocci antigens}

Patterns of IgG antibody reactivity against $S$. mutans (UA159), S. mitis (ATCC506), Ags were determined in Western blot as previously described (9). As negative controls, membranes were incubated only with blocking buffer, and as positive controls; membranes were incubated with a standard saliva sample obtained from an adult whose reaction pattern with antigen extracts had been previously measured. The secondary antibody was goat IgG anti-human IgG conjugated with horseradish peroxidase (Sigma, 1: 4,000 dilutions). Antibody reactions were developed using an ECL system (GE Healthcare UK, Little Chalfont, United Kingdom). For this purpose, immunoblots were incubated with ECL detection solution and then exposed to the same X-ray film for $5 \mathrm{~min}$. The developed X-ray films were scanned in a scanning densitometer (GE Healthcare) to analyze antigen recognition patterns, including the number of reactive bands. A film blank value was subtracted from the reactive band value.

\subsection{Statistical analysis}

A chi-square and Fisher's Exact Test tested comparisons of the frequencies of IgG antibody specificities. The mean number of IgG-reactive bands in Ags extracts was also determined and compared between antigens and samples and tested by ANOVA. A $p$-value of $<0.05$ was considered statistically significant.

\section{Results and Discussion}

\subsection{Frequency of IgG reactivity to $S$. mutans and $S$. mitis extracts in the samples}

The results show that $\operatorname{IgG}$ anti-S. mitis was found in a minority of blood samples (less than $22 \%$ ) (Table 1). On the other hand, the immunoassays showed that more than $95 \%$ of blood samples had IgG anti-S. mutans (Table 1). Comparative analysis of the bacterial strains revealed that $S$. mutans was more recognized than $S$. mitis both in $\mathrm{PB}$ and $\mathrm{CB}(\mathrm{p}<0.05)$. There was no difference in the frequency of presence of $\mathrm{IgG}$ anti-S. mutans between the blood samples (Tab. 1, $\mathrm{p}>0.05$ ). Immunoglobulin $\mathrm{IgG}$ represents systemic immunity and is present in whole saliva through the gingival fluid ${ }^{11}$ and can be associated to caries control ${ }^{18,21}$. A large amount of IgG antibodies against $S$. mutans were transferred from mother to child, as also detected for other species ${ }^{15,16,24}$. The findings of this study agree with previous data reported by Luo et al. ${ }^{18}$ who also detected antibodies against these oral streptococcal species. The repertory of IgG antibodies transferred to the fetus through the umbilical cord depends on the mother's contact with the antigen diversity to which she is exposed, explaining the less frequent detection and number of bands of $S$. mitis reactive $\mathrm{IgG}$ compared to $S$. mutans, since $S$. mitis is a microorganism frequently detected in infants during the first months of life and practically absent in adults ${ }^{1}$.

There was no significant difference in number of reactive bands between PB and CB for the two bacterial species (Table $1, \mathrm{p}>0.05$ ). Comparative analysis of $S$. mutans and $S$. mitis showed that the mean number of $S$. mutans IgG-reactive bands was significantly greater than for $S$. mitis extract in both $\mathrm{PB}$ and $\mathrm{CB}(\mathrm{p}>0.05)$.

Table 1 - Frequency of samples with IgG reactive to bacteria extracts and Mean number of reactive bands in the samples with a positive response to Streptococcus mutans and Streptococcus mitis antigens in PB (Peripheral Blood) and CB (Cord Blood) samples

\begin{tabular}{|l|c|c|c|c|}
\hline \multirow{2}{*}{} & \multicolumn{4}{|c|}{ Bacterial Extracts } \\
\cline { 2 - 5 } & \multicolumn{2}{|c|}{ SM } & SMI & \\
\cline { 2 - 5 } & $\boldsymbol{C B}$ & $\boldsymbol{P B}$ & $\boldsymbol{C B}$ & $\boldsymbol{P B}$ \\
\hline $\begin{array}{l}\text { Frequency of } \\
\text { samples with IgG } \\
\text { reactive to bacteria } \\
\text { extracts (\%) }\end{array}$ & $76(95)$ & $78(98)$ & $21(26)$ & $22(28)$ \\
\hline $\begin{array}{l}\text { Mean ( } \pm \text { SD) } \\
\text { number of reactive } \\
\text { bands }\end{array}$ & $\begin{array}{c}4.10 \pm \\
2.34\end{array}$ & $\begin{array}{c}4.71 \pm \\
2.38\end{array}$ & $\begin{array}{c}1.52 \pm \\
0.81\end{array}$ & $\begin{array}{c}1.68 \pm \\
0.94\end{array}$ \\
\hline
\end{tabular}

Source: Research data.

\subsection{Frequency of IgG reactivity against $S$. mutans antigens}

Data regarding the specificity of the presence of $\mathrm{IgG}$ reactive to the virulence antigens of $S$. mutans (Ag I/II, GTF and $\mathrm{GbpB})$ in $\mathrm{PB}(\mathrm{n}=78)$ and $\mathrm{CB}(\mathrm{n}=76)$ samples are presented in Table 2. Most $\mathrm{PB}$ and $\mathrm{CB}$ samples presented $\mathrm{IgG}$ against GbpB, while IgG positivity against Ag I/II was detected in about half the samples (Table 2) and Gtf was reactive in 29 and $41 \%$ of the $\mathrm{CB}$ and $\mathrm{PB}$ samples, respectively. There was no difference in frequency of $\mathrm{IgG}$ reactive to antigens between PB and CB (Table 2, $\mathrm{p}>0.05$ ).

The results revealed a high frequency of samples with IgG reactive to $\mathrm{GbpB}$, since more than $89 \%$ of the blood samples ( $\mathrm{PB}$ and $\mathrm{CB}$ ) contained $\mathrm{IgG}$ reactive to this protein, whereas 
$50 \%$ and $35 \%$ of the samples contained $\mathrm{IgG}$ reactive to $\mathrm{Ag} \mathrm{I} / \mathrm{II}$ and GtF, respectively. The presence of high concentration of IgG anti-GbpB was also detected by Chia et al ${ }^{17}$.

However, there was a significant difference in the detection frequency of Ag I/II- or Gtf-specific IgG compared to GbpB for both $\mathrm{PB}$ and $\mathrm{CB}$ (Table 2, $\mathrm{p}<0.05$ ) since the $\mathrm{IgG}$ reactive to $\mathrm{GbpB}$ was more frequent than the other antigens. There was also a difference between $\mathrm{Ag} \mathrm{I/II} \mathrm{and} \mathrm{Gtf} \mathrm{in} \mathrm{the} \mathrm{frequency}$ of a positive and negative response in $\mathrm{CB}$ since there was a higher prevalence of positivity for Ag I/II than for Gtf (Table $2, \mathrm{p}<0.05)$. There was a positive correlation in the frequency of IgG reactive or not to Ag I/II, GTF and GbpB between PB and $\mathrm{CB}(\mathrm{p}<0.05, \mathrm{r}>0.71)$.

Table 2 - Frequency and percentage of positive (Yes) and negative (No) responses to the Streptococcus mutans virulence antigens (Ag I/II, GTF and GbpB) in PB (n=78) and CB ( $\mathrm{n}=76)$ samples

\begin{tabular}{|l|c|c|c|c|}
\hline \multirow{2}{*}{$\begin{array}{c}\text { S.mutans } \\
\text { Ags: }\end{array}$} & \multicolumn{3}{|c|}{ Number (\%) of samples with reactive IgG } \\
\cline { 2 - 5 } & \multicolumn{2}{|c|}{$\operatorname{PB}(\mathrm{n}=78)$} & \multicolumn{2}{c|}{ CB $(\mathrm{n}=76)$} \\
\cline { 2 - 5 } & Yes & No & Yes & No \\
\hline Ag I/II & $45(58)^{\mathrm{a}}$ & $33(42)^{\mathrm{a}}$ & $37(49)^{\mathrm{c}, \mathrm{d}}$ & $39(51)^{\mathrm{c}, \mathrm{d}}$ \\
\hline Gtf & $32(41)^{\mathrm{b}}$ & $46(59)^{\mathrm{b}}$ & $22(29)^{\mathrm{C}, \mathrm{e}}$ & $54(71)^{\mathrm{C}, \mathrm{e}}$ \\
\hline GbpB & $71(91)^{\mathrm{A}, \mathrm{B}}$ & $7(9)^{\mathrm{A}, \mathrm{B}}$ & $68(89)^{\mathrm{D}, \mathrm{E}}$ & $8(11)^{\mathrm{D}, \mathrm{E}}$ \\
\hline
\end{tabular}

Superscript letters indicate statistically significant differences considering $\mathrm{p}<0.05,{ }^{\mathrm{a}, \mathrm{A}} \mathrm{Chi}$-square test, $\mathrm{p}<0.05, \mathrm{q}=22.76,{ }^{\mathrm{b}}{ }^{\mathrm{B}} \mathrm{Chi}$-square test, $\mathrm{p}<0.05$, $\mathrm{q}=43.46,{ }^{\mathrm{c},}{ }^{\mathrm{c}}$ Chi-square test, $\mathrm{p}<0.05, \mathrm{q}=6.23,{ }^{\mathrm{d}, \mathrm{D}}$ Chi-square test, $\mathrm{p}<0.05$, $\mathrm{q}=29.59,{ }^{e}, \mathrm{E} C h i-$ square test, $\mathrm{p}<0.05, \mathrm{q}=57.64$.

Source: Research data.

These maternal IgG antibodies in the newborn circulation start to decay during the first 3 months of life since they are metabolized and are accompanied by a gradual increase of the levels of the baby's own antibodies ${ }^{25}$. In newborns, the salivary IgA may not be able to combat the initial oral microbial colonization because they have low levels of IgA against virulence antigens, especially against $\mathrm{GbpB}^{10}$. Thus, the absence of salivary IgA against $S$. mutans and its virulence antigens may be compensated for IgG transferred during pregnancy and specific IgA with avidity for S. mutans in the in the colostrum ${ }^{26}$. However, it is necessary to determine the circulating IgG exit pathways into the neonates oral cavity and their role in oral colonization.

There was a positive correlation in the reactivity frequency or not to $S$. mutans between $\mathrm{PB}$ and $\mathrm{CB}$ (Pearson, $\mathrm{p}<005$, $\mathrm{r}=0.69)$. About 62 pairs of $\mathrm{PB}$ and $\mathrm{CB}$ samples $(77.5 \%)$ showed the same response to $S$. mutans and its antigens, with only 10 samples showing no response to GbpB among the pairs. Fourteen pairs showed partial similarities, i.e., they had at least one antigen in common, with $85 \%$ of them showing bands reactive to $\mathrm{GbpB}$ in $\mathrm{PB}$ and their respective $\mathrm{CB}$. Only 4 samples showed no total or partial similarity.

There was wide variability in the response of IgG between $\mathrm{PB}$ and CB. About $36 \%$ of PB samples showed a simultaneous response to the three $\mathrm{SM}$ antigens, as opposed to $25 \%$ of the $\mathrm{CB}$ samples. The most commonly detected response among the samples was a positive one to $\mathrm{Ag}$ I/II and GbpB simultaneously, as observed in $50 \%$ of the PB samples and 49 $\%$ of the CB samples.

\subsection{Comparison of the frequency of IgG-anti $S$. mutans and its antigens with the presence of genetic material of $S$. mutans in maternal saliva}

Sixty percent of mothers' salivas were positive for the $S$. mutans detection. No significant differences were detected between frequency of IgG-anti S. mutans and genetic material detection of $S$. mutans (Table 3, p>0.05). However, some differences were found in $\mathrm{CB}$ in comparison with $S$. mutans detection in the saliva. All samples of colonized mothers contained IgG anti-S. mutans, while $70 \%$ of non-colonized mothers had this antibody (Table $3, \mathrm{p}<0.05$ ). Also a significant difference was found in $\mathrm{CB}$ regarding the specific response to $\mathrm{GbpB}$, with $95 \%$ of the $\mathrm{CB}$ samples of colonized mothers containing IgG reactive to $\mathrm{GbpB}$, compared to $62 \%$ of noncolonized mothers (Table 3, $\mathrm{p}<0.05$ ).

No difference was detected between the frequency of samples with IgG reactivity to $S$. mutans and its antigens in $\mathrm{PB}$ and positive or negative bacteria detection in the saliva. However, in CB samples, $100 \%$ of the mothers carrying $S$. mutans in the saliva had IgG against $S$. mutans and $95 \%$ had $\mathrm{GbpB}$ reactive $\mathrm{IgG}$, differing from the pregnant women with undetectable S. mutans.

Table 3 - Frequency of saliva samples positive for the detection of Streptococcus mutans and IgG reactivity to Streptococcus mutans and its antigens in $\mathrm{PB}$ and $\mathrm{CB}$

\begin{tabular}{|c|c|c|c|c|}
\hline \multirow{2}{*}{$\begin{array}{c}\text { IgG } \\
\text { against }\end{array}$} & \multicolumn{2}{|c|}{ Number (\%) of samples with reactive IgG } \\
\cline { 2 - 5 } & \multicolumn{5}{|c|}{ Colonized N=20 } & \multicolumn{1}{c|}{ Non-Colonized N=13 } \\
\cline { 2 - 5 } & + & - & + & - \\
\hline S. mutans total extract \\
\hline PB & $20(100.0)$ & $0(0.0)$ & $12(92.3)$ & $1(7.7)$ \\
\hline CB & $20(100.0)^{\mathrm{a}}$ & $0(0.0)^{\mathrm{a}}$ & $9(69.2)^{\mathrm{A}}$ & $4(30.8)^{\mathrm{A}}$ \\
\hline \multicolumn{5}{|c|}{$\mathrm{Ag} \mathrm{I/II}$} \\
\hline PB & $13(65.0)$ & $7(35.0)$ & $6(46.2)$ & $7(53.8)$ \\
\hline CB & $11(55.0)$ & $9(45.0)$ & $4(30.8)$ & $9(69.2)$ \\
\hline \multicolumn{5}{|c|}{ Gtf } \\
\hline PB & $10(50.0)$ & $10(50.0)$ & $4(30.8)$ & $9(69.2)$ \\
\hline CB & $8(40.0)$ & $12(60.0)$ & $2(15.4)$ & $11(64.6)$ \\
\hline \multicolumn{5}{|c|}{ GbpB } \\
\hline PB & $19(95.0)$ & $1(5.0)$ & $10(76.9)$ & $3(23.1)$ \\
\hline CB & $19(95.0)^{\mathrm{b}}$ & $1(5.0)^{\mathrm{b}}$ & $8(61.5)^{\mathrm{B}}$ & $5(38.5)^{\mathrm{B}}$ \\
\hline
\end{tabular}

Superscript letters indicate statistically significant differences considering $\mathrm{p}<0.05$

Source: Research data.

S. mutans is known to be a common microorganism in the oral microbiota associated with the dental caries formation, but it causes a multifactorial disease in which a person harboring the bacterium in his or her oral cavity does not always have active disease. $S$. mutans may also be a transitory microorganism in the oral cavity, explaining the lack of $S$. mutans detection in the saliva of some puerperal who had reactive $\mathrm{IgG}$ in $\mathrm{PB}$. Mothers highly colonized by $S$. mutans may offer a large quantity of $\operatorname{IgG}$ antibodies against $S$. mutans 
to the neonate ${ }^{21}$. Maternal Staphylococcus aureus nasal colonization at delivery also was not associated with higher antibody levels in the newborns' mother ${ }^{16}$.

The degree of similarity in $\mathrm{PB}$ and $\mathrm{CB}$ regarding $\mathrm{IgG}$ specificity against SM and its virulence antigens was high since more than $85 \%$ of the pairs of samples showed the same response profile. These results support the possibility of immunoglobulins transference against $S$. mutans in the gestational period especially from the $30^{\text {th }}$ to $34^{\text {th }}$ week of gestation, when the antibodies passage is more intensified.

\section{Conclusion}

This study revealed that the majority of blood samples presented IgG against $S$. mutans, especially against GbpB. There is a similarity in $\mathrm{IgG}$ reactive to $S$. mutans and theirs virulence antigens in the $\mathrm{CB}$ and $\mathrm{PB}$. The $S$. mutans detection in the oral cavity is associated to IgG presence in the samples

\section{Acknowledgments:}

This study was supported by Fundação de Apoio a Pesquisa de Minas Gerais e Coordenação de Aperfeiçoamento de Pessoal de Nível Superior (2848/2011).

\section{References}

1. Cota ALS, Silva V, Silva SMB. Virulence of Streptococcus mutans: An intrafamilial cohort study on transmission of genotypes. J Clin Exp Dent 2020;12(1):e59-e64. doi: 10.4317/medoral.56038.

2. Caufield PW, Cutter GR, Dasanayake AP. Initial acquisition of mutans streptococci by infants: evidence for a discrete window of infectivity. J Dent Res 1993;72(1):37-45. doi: $10.1177 / 00220345930720010501$

3. Alves AC, Nogueira RD, Stipp RN, Pampolini F, Moraes AB, Goncalves RB, et al. Prospective study of potential sources of Streptococcus mutans transmission in nursery school children. J Med Microbiol 2009;58:476-81. doi: 10.1099/ jmm.0.005777-0

4. Lynch DJ, Villhauer AL, Warren JJ, Marshall TA, Dawson DV, Blanchette DR, et al. Genotypic characterization of initial acquisition of Streptococcus mutans in American Indian children. J Oral Microbiol 2015;7:27182. doi: 10.3402/jom. v7.27182

5. Childers NK, Momeni SS, Whiddon J, Cheon K, Cutter GR, Wiener HW, et al. Association Between Early Childhood Caries and Colonization with Streptococcus mutans Genotypes From Mothers. Pediatr Dent 2017;39(2):130-5.

6. Rosenblatt R, Steinberg D, Mankuta D, Zini A. Acquired oral microflora of newborns during the first 48 hours of life. J Clin Pediatr Dent 2015;39(5):442-6. doi: 10.17796/1053-462839.5.442

7. Liao S, Klein MI, Heim KP, Fan Y, Bitoun JP, Ahn SJ, et al. Streptococcus mutans extracellular DNA is upregulated during growth in biofilms, actively released via membrane vesicles, and influenced by components of the protein secretion machinery. J Bacteriol 2014;196(13):2355-66. doi: 10.1128/JB.01493-14

8. Patel M. Dental caries vaccine: are we there yet? Lett Appl Microbiol 2020;70(1):2-12. doi: 10.1111/lam.13218.
9. Nogueira RD, Alves AC, Napimoga MH, Smith DJ, MattosGraner RO. Characterization of salivary immunoglobulin A responses in children heavily exposed to the oral bacterium Streptococcus mutans: influence of specific antigen recognition in infection. Infect Immun 2005;73(9):5675-84. doi: 10.1128/IAI.73.9.5675-5684.2005

10. Borges MC, Sesso ML, Roberti LR, de Menezes Oliveira MA, Nogueira RD, Geraldo-Martins VR, et al. Salivary antibody response to streptococci in preterm and fullterm children: a prospective study. Arch Oral Biol 2015;60(1):116-25. doi: 10.1016/j.archoralbio.2014.08.003

11. Brandtzaeg P. Do salivary antibodies reliably reflect both mucosal and systemic immunity? Ann N Y Acad Sci 2007;1098:288-311. doi: 10.1196/annals.1384.012

12. Simister NE, Story CM, Chen HL, Hunt JS. An IgGtransporting $\mathrm{Fc}$ receptor expressed in the syncytiotrophoblast of human placenta. Eur J Immunol 1996;26(7):1527-31. doi: 10.1002/eji.1830260718

13. Brandtzaeg P. Secretory immunity with special reference to the oral cavity. J Oral Microbiol 2013;5. doi: 10.3402/jom. v5i0.20401

14. van Der Zwet WC, Vandenbroucke-Grauls CM, van Elburg RM, Cranendonk A, Zaaijer HL. Neonatal antibody titers against varicella-zoster virus in relation to gestational age, birth weight, and maternal titer. Pediatrics 2002;109(1):7985. doi: $10.1542 /$ peds.109.1.79

15. Stach SC, Brizot ML, Liao AW, Palmeira P, Francisco RP, Carneiro-Sampaio MM, et al. Placental transfer of IgG antibodies specific to Klebsiella and Pseudomonas LPS and to group B Streptococcus in twin pregnancies. Scand J Immunol 2015;81(2):135-41. doi: 10.1111/sji.12258

16. Nadaf MI, Lima L, Stranieri I, Takano OA, Carneiro-Sampaio M, Palmeira P. Passive acquisition of anti-Staphylococcus aureus antibodies by newborns via transplacental transfer and breastfeeding, regardless of maternal colonization. Clinics (Sao Paulo) 2016;71(12):687-94. doi: 10.6061/ clinics/2016(12)02

17. Chia JS, Chang WC, Yang CS, Chen JY. Salivary and serum antibody response to Streptococcus mutans antigens in humans. Oral Microbiol Immunol 2000;15(2):131-8. doi: 10.1034/j.1399-302x.2000.150210.x

18. Luo Z, Smith DJ, Taubman MA, King WF. Crosssectional analysis of serum antibody to oral streptococcal antigens in children. J Dent Res 1988;67(3):554-60. doi: $10.1177 / 00220345880670030601$

19. Gomez SI, Jaramillo LM, Moreno GC, Roa NS, Rodriguez A. Differential reactivity of salivary igA and igG against streptococcus mutans proteins in humans with different caries experience. Acta Odontol Latinoam 2015;28(1):3-12. doi: $10.1590 / \mathrm{S} 1852-48342015000100001$

20. Patel AS, Chandak M, U. MN, Shori DD, Vinod MA. Estimation of immunoglobulin levels in saliva and serum in relation to dental caries in population of central India. Int $\mathbf{J}$ Clin Dent 2013;6(4):383-8.

21. Aaltonen AS, Tenovuo J, Lehtonen OP. Antibodies to the oral bacterium Streptococcus mutans and the development of caries in children in relation to maternal dental treatment during pregnancy. Arch Oral Biol 1988;33(1):33-9. doi: 10.1016/0003-9969(88)90093-3

22. Mohamad WMW, Aziz WNABW, Ismail NM, Basri R, Alam MK. Association between Immunological Status and Caries Experience among Adults Attending Hospital Universiti 
Sains Malaysia (HUSM). Int Med J 2013;20(2):208-10.

23. Chen Z, Saxena D, Caufield PW, Ge Y, Wang M, Li Y. Development of species-specific primers for detection of Streptococcus mutans in mixed bacterial samples. FEMS Microbiol Lett 2007;272(2):154-62. doi: 10.1111/j.15746968.2007.00756.x

24. Nagao AT, Friedlander-Del Nero D, Arslanian C, CarneiroSampaio MM. Elevated levels and different repertoire profile of colostral anti-LPS antibodies may have a significant role in compensating newborn immunity. Scand J Immunol 2001;53(6):602-9. doi: 10.1046/j.1365-3083.2001.00921.x
25. Ballow M, Cates KL, Rowe JC, Goetz C, Desbonnet C. Development of the immune system in very low birth weight (less than $1500 \mathrm{~g}$ ) premature infants: concentrations of plasma immunoglobulins and patterns of infections. Pediatr Res 1986;20(9):899-904. doi: 10.1203/00006450-19860900000019

26. Petrechen LN, Zago FH, Sesso ML, Bertoldo BB, Silva CB, Azevedo KP, et al. Levels and complexity of $\operatorname{IgA}$ antibody against oral bacteria in samples of human colostrum. Immunobiology 2015;220(1):142-6. doi: 10.1016/j. imbio.2014.08.009. 